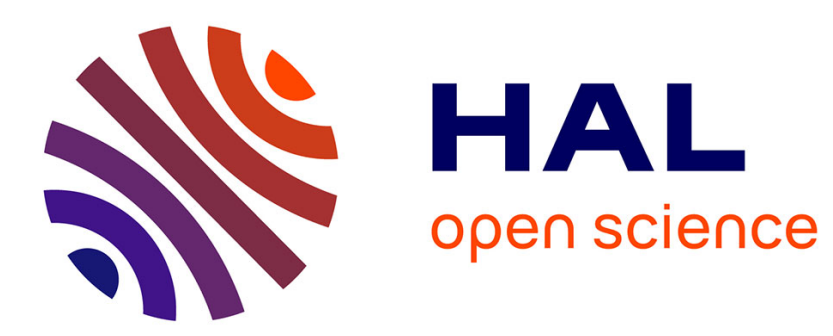

\title{
The Contents and Features of Dispute Settlement under US-Jordan FTA: An Appraisal
}

\author{
Bashar H Malkawi
}

\section{To cite this version:}

Bashar H Malkawi. The Contents and Features of Dispute Settlement under US-Jordan FTA: An Appraisal. Manchester Journal of International Economic Law, 2018. hal-02293204

\section{HAL Id: hal-02293204 \\ https://hal.science/hal-02293204}

Submitted on 20 Sep 2019

HAL is a multi-disciplinary open access archive for the deposit and dissemination of scientific research documents, whether they are published or not. The documents may come from teaching and research institutions in France or abroad, or from public or private research centers.
L'archive ouverte pluridisciplinaire HAL, est destinée au dépôt et à la diffusion de documents scientifiques de niveau recherche, publiés ou non, émanant des établissements d'enseignement et de recherche français ou étrangers, des laboratoires publics ou privés. 


\title{
The Contents and Features of Dispute Settlement under US-Jordan FTA: An Appraisal
}

\author{
Bashar H. Malkawi*
}

\section{Introduction}

The U.S.-Jordan Free Trade Agreement (hereinafter US-JO FTA) was the first FTA to be concluded with an Arab country. Several reasons led the U.S. to negotiate a free trade agreement with Jordan. The failed WTO Ministerial Conference in 1999 lead U.S. trade officials to analyze the possibilities for a free trade agreement that would include certain provisions that are resisted at the multilateral trading level. ${ }^{1}$ Moreover, the U.S. and Jordan had signed a trade and investment framework in 1999, which is usually a precursor for a FTA. ${ }^{2}$

Jordan was also the right candidate for a FTA in terms of economics and politics. Economically, U.S. exports to Jordan would increase as a result of the FTA while Jordanian imports to the U.S. would not threaten U.S. industries. ${ }^{3}$ The FTA could also spur Jordan's economic growth, allowing for the possibility that it would become less

\footnotetext{
* Dean and Professor of Law, College of Law, University of Sharjah (contact: bmalkawi@sharjah.ac.ae). The author wishes to thank David Gantz and Padideh Ala'i for their indispensable comments and feedback they provided in connection with the preparation of this article. The author also would like to thank Zeina Ahmad for her research assistance.

${ }^{1}$ In the wake of protests by environmentalists and human rights activists at the WTO summit in Seattle in late 1999, then president Clinton promised to link future trade accords to labor, environmental, and human rights issues. See Eric M. Uslaner, The Democratic Party and Free Trade: An Old Romance Restored, 6 NAFTA: L \& Bus. Rev. Am. 347, 359 (2000).

${ }^{2}$ See Grary G. Yerkey, U.S., Jordan Sign Framework For Trade and Investment Pact, 16 Intl. Trade Rep. (BNA) 468 (Mar. 17, 1999) (then USTR Charlene Barshefsky stated that the agreement would put in place institutional foundation for trade relationship. The agreement opened dialogue on issues such as agriculture, intellectual property, services, investment, and trade-related aspects of labor and environmental policy).

${ }^{3}$ A study conducted by the Office of Economics and the Office of Industries of the USITC, found that "Jordan's exports to the U.S. would not have a measurable impact on U.S. industries, U.S. employment, and production. Based on 1999 trade figures, U.S. imports from Jordan totaled \$31 million as compared to total US imports of \$1 trillion. See U.S. International Trade Commission, Economic Impact on the United States of a U.S.-Jordan Free Trade Agreement, 5-1 Pub. No. 3340 (Sep. 2000) (an FTA with Jordan is not expected to have a measurable impact on U.S. imports from Jordan for the 15 sectors reviewed. For one sector, textiles and apparels, a likely rise in U.S. imports of apparel is expected to have a negligible effect on total U.S. imports).
} 
dependant on foreign aid. Moreover, the U.S. needed to negotiate a FTA because it was

losing ground to the EC which, which had concluded association agreements with several Mediterranean countries. ${ }^{4}$ By signing the FTA, the U.S. could catch up to the EC with respect to economic dominance in Arab countries.

Politically, the FTA reflects the U.S.'s appreciation for Jordan's role in the Middle East peace process and cooperation with international counter-terrorism activities. In addition, the FTA signals to other Arab countries the benefits to maintain peace. Economic growth will also enhance political stability and encourage peace in the Middle East. ${ }^{5}$ For its part, the U.S. would be able to market Jordan's economic growth as a product of Jordan's peaceful relationship with its neighbors, especially Israel. In other words, a wealthy Jordan is good for Israel. ${ }^{6}$ So long as Jordan remains poor its citizens, who are mostly Palestinians, will continue to blame their poverty on Israel. Therefore, the FTA would also help alleviate the pressure on Israel and reduce its security risk.

\footnotetext{
${ }^{4}$ The official movement towards a closer relationship between the EC and its Mediterranean neighbors was launched at a meeting of the European Council in Lisbon in 1992. It takes place between the EC and 12 countries to the east and south of the Mediterranean. The major premise of the partnership is to create an enormous zone of free trade between Europe and several countries of the Middle East. The EuroMediterranean Partnership was created in 1995 in Barcelona with the signing of the Barcelona Declaration by the EC and 12 Mediterranean Countries. The 12 Mediterranean countries are as follows: Morocco, Algeria, Tunisia, Egypt, Jordan, Israel, The Palestinian Authority, Lebanon, Syria, Cyprus, Malta, and Turkey. This partnership will lead to a series of Euro-Mediterranean association agreements. See Jacqueline Klosek, The Euro-Mediterranean Partnership, 8 Intl. Leg. Persp. 173 (1996).

${ }^{5}$ See Bashar Malkawi, Securing Peace through Trade Dividends: Qualifying Industrial Zones between the U.S, Israel, Jordan, and Egypt, 13 Currents: International Trade Law Journal 3, 5 (2004). See also David Gantz, Introduction to U.S. Free Trade Agreements, 5 British Journal of American Legal Studies 300, 308 (2016).

${ }^{6}$ Of particular importance are the opportunities the agreement potentially provides Palestinians living in Jordan. For these individuals, nearly all of whom at present live in poverty and have little chance to improve their lives, FTA changes the equation and offers real hope. Significantly, it offers a tangible alternative to violence. President Kennedy who said "trade, not aid." See Sen. Comm. on Finance, Hearing on Jordan Free Trade Agreement, 107th Cong. 1st Sess. (Mar. 20, 2001) (statement of Sen. Bingaman). That view is held by Israeli Prime Minister Sharon, who, on his first visit to Washington as prime minister, urged Congress to pass this historic trade agreement.
} 
On June 6, 2000, King Abdullah II and then President Clinton declared that the U.S. and Jordan would launch negotiations for a free trade agreement. ${ }^{7}$ The US-JO FTA was signed in a record time on October $24,2000 .^{8}$ It was the first FTA to be concluded in the absence of fast track authority, which had lapsed since $1994 .{ }^{9}$ Without fast track authority, congressional approval for the FTA would be subject to regular procedures.

The US-JO FTA is comprised of a preamble, nineteen articles, three annexes, joint statements, memorandums of understanding, and side letters. The preamble of the US-JO FTA lists the aims of the agreement. For example, the FTA partners desire to further the historic bonds of friendship between them. ${ }^{10}$

Articles 15, 16, and 17 of the US-JO FTA are related to the dispute settlement mechanism. ${ }^{11}$ Theses articles provide an umbrella under which any dispute may be resolved. The provisions apply to all legal disputes arising from the FTA, with the

\footnotetext{
${ }^{7}$ See Gary G. Yerkey, U.S., Jordan Make "Substantial" Progress in Talks on Free Trade Agreement, USTR Says, 17 Intl. Trade Rep. (BNA) 1224 (Aug. 3, 2000) (stating agreement to initiate negotiations was announced by U.S. officials following a meeting between President Clinton and King Abdullah on June 6 in Washington, D.C.).

${ }^{8}$ This record time of approximately four months can be compared with the 15 months of intensive debate between the U.S. and Israel which resulted in the conclusion of the US-Israel FTA. See Andrew James Samet \& Moshe Goldberg, The U.S.-Israel Free Trade Area Agreement 1.02 (Bus. L. 1989). NAFTA parties completed negotiations in 1992 after 14 months of negotiations.

${ }^{9}$ The fast track authority is a procedure, delegated by the U.S. Congress, gives the U.S. executive the authority to enter into trade negotiations under certain procedural requirements. It was used to conclude the Tokyo Round of 1979, the US-Israel FTA of 1985 whereby a specific section (section 401) of the U.S. Trade and Tariff Act of 1984 was designed as "trade with Israel", the US-Canada FTA of 1988, NAFTA of 1993, and the Uruguay Multilateral Trade Round of 1994. For more on fast track authority see I.M Destler, Renewing Fast-Track Legislation 8 (Inst. Intl. Econ. 1997).

${ }^{10}$ See United States (U.S.)-Jordan: Agreement Between The United States of America and the Hashemite Kingdom of Jordan on The Establishment of a Free Trade Area, Oct. 24, 2000, 41 I. L. M. 63 (entered into force Dec. 17, 2001), preamble.

${ }^{11}$ Articles 17 (Joint Committee), 18 (Notice and Consultation), and 19 (Dispute Settlements) of the USIsrael FTA are related to the dispute settlement mechanism. Chapter 20 of NAFTA (Institutional Arrangements and Dispute Settlement Procedures) covers disputes settlement under the agreement.
} 
exception of matters involving services, which is found in article 3, and intellectual

property rights, which is found in article $4 .^{12}$

The following discussion analyzes the dispute settlement mechanism provided for by the US-JO FTA. ${ }^{13}$ The article begins in section II with a brief introduction on the functioning of FTAs. Section III highlights the importance of including dispute resolution provisions in FTAs. Section IV analyzes the controlling procedure with respect to disputes includes: the Joint Committee of the FTA; standard of review; establishment and composition of panels; application and range of resolutions for disputes; panel report; transparency; forum shopping; the effect of rulings or recommendations; and implementation issues. Section V discusses the special dispute settlement rules for labor and environmental disputes. Section VI assesses the use of dispute resolution mechanism under the US-JO FTA. The article concludes by proposing improvements to the US-JO FTA dispute resolution mechanism and additions to its existing provisions.

\footnotetext{
${ }^{12}$ Subparagraph 17.4.a of the FTA provides "A Party may invoke a panel under paragraph 1.c of this Article for claims arising under Article 3 [services] only to the extent that a claim arises with regard to a commitment that is inscribed in the Party's Services Schedule to Annex 3.1 to this Agreement, but is not inscribed in the Party's Schedule of specific commitments annexed to GATS. Such commitment may include a market access or national treatment commitment in a sector, a horizontal commitment applicable to a sector, or additional commitment". Additionally, subparagraph 17.4.b provides "Except as otherwise agreed by the Parties, a Party may invoke a panel under paragraph 1.c of this Article for claims arising under Article 4 [intellectual property] only to the extent that the same claim would not be subject to resolution through the WTO Understanding on Rules and Procedures Governing the Settlement of Disputes".

${ }^{13}$ A comparison, whenever necessary, is made with the U.S.-Israel Free Trade Agreement ("US-Israel FTA") and other U.S. FTAs' with Arab countries such as Oman, Bahrain, and Morocco. These FTAs were chosen for the purposes of analysis because the U.S. signed FTAs' only with Israel, a next-door neighbor, and other Arab countries in the region. In addition, reference will be made to WTO agreements and panel decisions. See United States-Standards for Reformulated and Conventional Gasoline, Apr. 29, 1996, WTO Doc. No. WT/DS2/AB/R, at 17 (that direction reflects a measure of recognition that the General Agreement is not to be read in "clinical isolation" from public international law). See also JOOST PAUWELYN, CONFLICT OF NORMS IN PUBLIC INTERNATIONAL: HOW WTO LAW RELATES TO OTHER RULES OF INTERNATIONAL LAW 25-40 (2003) (stating that no academic author, WTO decision or document dispute that WTO rules are part of the wider corpus of public international law).
} 


\section{Global Economics and FTAs}

International trade constitutes a vital lynchpin of the global governance architecture with staggering trillions of U.S. dollars worth of annual trade. ${ }^{14}$ The global trade order consists of trade policies and systems - in particular FTAs - which have played an increasingly crucial role in the infrastructure of global governance and substantially impacting international economic development and strategic affairs. ${ }^{15}$ The trade infrastructure is inextricably linked with global financial institutions and power politics and intertwined with military and political alliances. ${ }^{16}$

In recent decades, global economic governance has promoted free trade and trade liberalization through regional trade agreements (RTAs) to improve economic welfare of which FTAs form the overwhelming majority of agreements. ${ }^{17}$ FTAs have been perceived as stoking global economic growth as well fostering vigorous economic benefits to trade partners and gained in popularity following the failures to implement

\footnotetext{
${ }^{14}$ In 2016, there was U.S. \$20 trillion worth of global trade in goods and services. See WTO, World Trade Statistical Review, available at <https://www.wto.org/english/res_e/statis_e/wts2016_e/wts2016_e.pdf $>, 18$ (2016).

${ }^{15}$ See Joel Slawotsky, The Clash of Architects: Impending Developments and Transformations in International Law, 3 The Chinese Journal of Global Governance (2017) (International trade agreements may encompass broader, geopolitical and concerns global governance contexts have always played a role in investment treaty law)

${ }^{16}$ Helen Milner, The Political Economy of International Trade, 2 Annu. Rev. Polit. Sci. 105, 118 (1999). Power politics matters in the global trade paradigm as powerful states may violate their trade commitments toward weaker trading partners, knowing that weaker states are unlikely to carry out retaliation against them. See Anu Bradford \& Eric A. Posner, Universal Exceptionalism in International Law, 52 Harvard International Law Journal 3, 11 (2011).

${ }^{17}$ See Chankwon Bae and Yong Joon Jang, The Impact of Free Trade Agreements on Foreign Direct Investment: The Case of Korea, 17 Journal of East Asian Economic Integration 417, 423(2013) (In particular, free trade agreements (FTAs) [], account for $90 \%$ of the total number of RTAs.) See also Bashar H. Malkawi, Rules of origin under US Trade Agreements with Arab countries: Are they Helping and Hindering Free Trade? 10 Journal of International Trade Law and Policy 29, 33 (rules of origin in some FTAs are complex and protectionist and may act as barriers to trade).
} 
World Trade Organization modifications post-Doha leading to proliferation of FTAs in the early $2000 \mathrm{~s} .{ }^{18}$

FTAs are contractual obligations between the parties to reduce or eliminate tariffs and other trade restrictions on imports and a wide array of economic sectors. ${ }^{19}$ The goals of FTAs are to promote cross-border trade and investment and provide a stimulus to the economy of the trade partners. FTAs arise from perceptions between trading partners that an FTA would benefit the partners by - at a minimum - reducing or eliminating trade barriers and tariffs and establishing rules with respect to what constitutes a product manufactured within the FTA i.e. rules of origin. ${ }^{20}$

There are many benefits ascribed to FTAs such as vigorous global trade and encouraging efficient allocation of resources, enhanced consumer options and overall lower economic costs. FTAs are widely acknowledged as promoting trade liberalization and access to markets creating a more dynamic economic environment. Trade is considered as an important catalyst of economic growth. Trade promotes more efficient and effective production of goods and services to the countries which have comparative

\footnotetext{
${ }^{18}$ See Masahiro Kawai and Ganeshan Wignaraja, Free Trade Agreements in East Asia: A Way toward Trade Liberalization? Available at $<$ https://www.adb.org/sites/default/files/publication/28490/adb-briefs2010-1-free-trade-agreements.pdf $>$ (2010) (The inability to conclude the World Trade Organization (WTO) Doha Development Round has spawned a proliferation of bilateral and plurilateral free trade agreements (FTAs) across the globe) See also Hitoshi Sato, and Ikumo Isono, Impacts of Free Trade Agreements on Business Activity in Asia: The Case of Japan Daisuke Hirastuka, available at $<$ https://www.adb.org/sites/default/files/publication/155998/adbi-wp143.pdf> p.2 (2009) page 2 (Efforts to liberalize global trade through the World Trade Organization (WTO) have made limited progress since the Doha round of negotiations was launched in 2001.... [The] disappointing consequences have forced the WTO member countries (US and EU in particular) to choose alternative paths such as FTAs to promote trade. The trend toward FTAs has generated a domino effect in which one FTA triggers the creation of others). See also Julien Chaisse and Mitsuo Matsushita, Maintaining the WTO's Supremacy in the International Trade Order: A Proposal to Refine and Revise the Role of the Trade Policy Review Mechanism, 16 Journal of International Economic Law 9, 18-20 (2013).

${ }^{19}$ See, e.g., Korea FTA chs. 3, 7, 11, 12, and 18, 46 I.L.M. 642 (2007).

${ }^{20}$ William H. Cooper, Free Trade Agreements: Impact on U.S. Trade and Implications for U.S. Trade Policy, p.2-4 (2014), available at <https://fas.org/sgp/crs/row/RL31356.pdf > (Rules of origin prevent products from nonmembers entering an FTA market over the lowest tariff wall. Most FTAs also include procedures on the settlement of disputes arising among members and rules on the implementation of border controls, such as product safety certification and sanitary and phytosanitary requirements)
} 
advantage in producing them. ${ }^{21}$ The economic benefits of FTAs are so well-recognized that even on an individual business person level, let alone company level, there is a strong interest in pursuing FTAs. ${ }^{22}$ FTAs could also provide other less tangible benefits. The signing of FTAs not only signifies economic cooperation between nations, but also cooperation on the political and institutional fronts. ${ }^{23}$

Indeed, expert economic consensus is that free trade fosters wealth gains and raises living standards. Moreover, in addition to economic benefits, FTAs have been viewed favorably as a tool of broad strategic goals. ${ }^{24}$ Therefore, in an effort to expand export, promote employment and wealth creation, almost every country has attached great significance to FTAs, which are regarded as an important approach to promote national economy and trade development. Most WTO member countries have signed at least one FTA.

The surging movement of foreign direct investment (FDI) across borders is a significant outcome of globalization and is an important component of economic growth. FDI is considered a pillar of economic stability and growth and FTAs are widely

\footnotetext{
${ }^{21}$ See Najabat Ali, Li Xialing, Foreign Direct Investment, International Trade and Economic Growth in Pakistan's Economic Perspective, 7.5 American Journal of Economics 211-215 (2017).

${ }^{22}$ See Jeffrey J. Schott, Free Trade Agreements: The Cost of U.S. Nonparticipation, Testimony before the Subcommittee on Trade. House Ways and Means Committee (March 29, 2001) (arguing that to counter the fact that FTAs are rapidly forming in which the United States is not a participant, the US must vigorously negotiate FTAs or risk harming US interests).

${ }^{23}$ See S. M. Thangavelu and C. Findlay, The Impact of Free Trade Agreements on Foreign Direct Investment in the Asia-Pasific Region, in Findlay, C. (ed.), ASEAN+1 FTAs and Global Value Chains in East Asia, ERIA Research Project Report 2010-29 (2011).

${ }^{24}$ Interestingly, the U.S. had arrived relatively late to the conclusion that regional trade agreements were a desirable and even necessary element of a comprehensive trade liberalization policy. Throughout multiple GATT negotiating rounds designed to achieve global tariff and non-tariff barrier reductions, at least through the Tokyo Round (1973-79), the United States remained a strong supporter of the multilateral trading system. The shift toward Regional Trade Agreements (RTAs) began only in the mid-1980s. see David A. Gantz, supra note 5, at 305.
} 
understood as a proximate cause of increasing FDI. ${ }^{25}$ Political legitimacy and binding nature of these FTAs help to create a more secure political and institutional environment for multinational corporations to invest, thereby increasing FDI flows. FTAs are also important during global financial problems as FTAs serve to keep trade and FDI flowing, even when crises strike. ${ }^{26}$

FTAs and free trade are not without criticism. Although the essential construct of FTAs is tariff and barrier elimination, more recent FTAs are more ambitious and include chapters on investment rules and intellectual property rights in a way that go beyond what is covered by the GATT/WTO ${ }^{27}$ In addition, opposing economists claim that FTAs are inferior to the WTO order and they undermine the multilateral trading system. ${ }^{28}$

A major criticism of FTAs arises from the inherent technology transfer and flow of investment capital across borders. Critics point to the purported "greater benefit to the partner nation than to the United States" to claim FTAs such as NAFTA enable some nations to exploit the FTA and partners to be a 'trade sucker". ${ }^{29}$ Some FTAs such as NAFTA depresses wages, result in lost jobs and sharpens national income inequality. ${ }^{30}$

\footnotetext{
${ }^{25}$ FTAs are increasingly being used as instruments to promote political diplomacy. Thangavelu, S. M. and C. Findlay, supra note 23, at 114 .

${ }^{26}$ See Masahiro Kawai and Ganeshan Wignaraja, Free Trade Agreements in East Asia: A Way toward Trade Liberalization? 1 Asian Development Bank Briefs 4 (2010).

${ }^{27}$ See Vergano R. Paolo and Tobias Dolle, Free Trade Agreements and Regulatory Change: Examples from the Generic and Biosimilar Sectors, 51 Journal of World Trade 205, 208 (2017).

${ }^{28}$ International economists such as Jagdish Bhagwati and Anne O. Krueger strongly advocate that the U.S. and other national governments should not pursue FTAs at the expense of multilateral negotiations in the WTO. FTAs are by definition discriminatory and therefore trade diverting. See William H. Cooper, Free Trade Agreements: Impact on U.S. Trade and Implications for U.S. Trade Policy Specialist in International Trade and Finance 11 (2014).
}

\footnotetext{
${ }^{29}$ The counter-argument is that while benefits may indeed flow to a partner nation, this does not translate into the United States being a "sucker." See Gary Clyde Hufbauer, Cathleen Cimino, and Tyler Moran, NAFTA at 20: Misleading Charges and Positive Achievements 18 (May 2014) (At the launch of a free trade agreement (FTA), US trade barriers are almost always lower than the barriers of a prospective partner
} 
Another avenue of criticism is that FTAs may adversely impact human rights and labor rights. ${ }^{31}$ FTAs should not stomp on human rights and there should be no interference into the domestic regulation of budgetary, health, environmental and other public policies.

\section{The Importance of Dispute Settlement Provisions in FTAs}

It is assumed that the parties to the FTA will carry out their commitments in good faith. Persons and companies would risk capital and may suffer potential loss; therefore FTAs require a strong legal foundation incentivizing stability, transparency and compliance with obligations. Legal guarantees and the knowledge disputes will be fairly adjudicated with appropriate remedies is the cornerstone of encouraging FTA utilization. ${ }^{32}$ To provide the inducement, FTAs provide that failure to comply with FTA obligations may trigger the dispute resolution mechanism and result in retaliatory measures or a claim for damages or the imposition of a fine or other negative consequence. ${ }^{33}$ Even if no disputes are expected, dispute settlement provisions in a FTA

\footnotetext{
country. Why? Because, unlike many countries, the United States has progressively trimmed its trade barriers for 70 years, since the end of the Second World War. Lower US trade barriers at the launch of the agreement were true of the Canada-US FTA (CUSFTA) in 1989; NAFTA, which added Mexico in 1994; the US-Chile FTA in 2004; the US-Australia FTA in 2005; the US-Peru FTA in 2009; the US-Korea FTA in 2012; and others. Since the goal of any FTA is to reduce the trade barriers of both partners to zero, the US partner almost always has further to go....FTAs also lower nontariff barriers (NTBs, for example, quotas and regulatory obstacles) in both partners. Extensive research shows that, like tariffs, NTBs are generally higher in the partner country when an FTA is launched. Again, the partner has further to go. So, just looking at negotiated FTA texts, it is "Uncle Smart," not "Uncle Sucker.")

${ }^{30} I d$.

${ }^{31}$ See Meredith Kolsky Lewis, Human Rights Provisions in Free Trade Agreements: Do the Ends Justify the Means? 12 Loy. U. Chi. Int'l L. Rev. 1, 6-8 (2014).

${ }^{32}$ The way in which an international treaty ensures that its signatories actually comply with their treaty obligations is one of the critical factors determining the effectiveness and efficiency of the treaty. See Abram Chayes and Antonia Handler Chayes, The New Sovereignty; Compliance with International Regulatory Agreements 3-4 (1995).

${ }^{33}$ See for example NAFTA chs. 11, 20, Can.-Mex.-U.S., Dec. 17, 1992, 32 I.L.M. 289 and 605 (1993); Korea FTA chs. 11, 22.
} 
reinforce commitments of parties and assure investors that the FTA provides a solid ground for investment.

The dispute settlement mechanism in FTAs is necessary as they provide means to settle disagreements on interpretation or compliance with treaty obligations. The dispute settlement mechanism help ease tensions among FTA parties and maintain healthy relationships among trading partners. ${ }^{34}$ To put is differently, dispute settlement provisions in FTAs provide an organized way for its members to settle disputes otherwise lingering disputes can harm bilateral relations and reduce the FTAs' benefits.

In addition to preventing spillovers of disputes, dispute resolution mechanism is considered crucial tool to provide an authoritative interpretation of the rules and norms of a treaty. ${ }^{35}$ This can enhance commitments of the parties and legitimacy of the FTA itself. Ultimately, the existence of dispute resolution mechanism in FTAs is fundamental to the process of economic integration as it facilitates a deeper and wider integration by providing an institutional framework of jurisprudence to develop and increase access to justice by members of the FTA. ${ }^{36}$

The existence of dispute resolution mechanism shifts the balance in FTAs from power-oriented to rule-oriented legal systems. ${ }^{37}$ In recent years, a large amount of criticism has been leveled against dispute settlement mechanisms in FTAs. For example, FTAs in general, and their dispute resolution provisions in particular, are seen as a means by which developed countries to export their laws into the other countries that are party

\footnotetext{
${ }^{34}$ Dispute resolution mechanism can reduce the number of economic and political disputes that could lead to military conflict. See E.D. Mansfield and B.M. Pollins (eds.), Economic Interdependence and International Conflict: New Perspectives on an Enduring Debate 222-224 (2003). See also Yuval Shany, The Competing Jurisdictions of International Courts and Tribunals 3-5 (2003).

${ }^{35}$ See Abram Chayes and Antonia Handler Chayes, supra note 27, at 24.

${ }^{36}$ See David Simmons, Caribbean Court of Justice: A Unique Institution of Caribbean Creativity, 29 Nova L. Rev. 171, 177-178 (2005).

${ }^{37}$ See John H. Jackson, The World Trading System, 110-11 (2ed., 1997).
} 
to the FTAs. ${ }^{38}$ Furthermore, dispute settlement provisions are considered as overriding domestic court systems and sovereignty. ${ }^{39}$ Despite the criticism leveled against dispute resolution mechanisms, their presence in FTAs is of paramount importance in providing stability and incentive for parties to engage in trade. If dispute settlement mechanism fails at encouraging trade, FTAs will not be as successful as the potential. Thus, the dispute settlement mechanism is an important or perhaps even overriding focus in the establishment of FTAs.

\section{The US-JO FTA Dispute Settlement Mechanism}

\section{A. The Joint Committee of the US-JO FTA}

Articles 15 and 16 of the US-JO FTA emphasize the settlement of disputes through consultations. The US-JO FTA establishes a permanent body, called the Joint Committee, to review the implementation of the FTA. ${ }^{40}$ The Joint Commission is comprised of cabinet level representatives or their delegates; for the U.S it is USTR and for Jordan Minister of Trade and Industry. ${ }^{41}$

The Joint Commission's responsibilities go well beyond dispute settlement, and include: reviewing the general functioning of the agreement and the results of the agreement from experience gained during its functioning, considering and adopting any amendment or modification to the agreement subject to the domestic legal requirements of each party, and developing guidelines, explanatory materials, rules on the proper implementation of the agreement, and discussing the review performed by each part as to

\footnotetext{
${ }^{38}$ See Mark B. Baker, No Country Left Behind; Exporting of U.S. Legal Norms Under the Guise of Economic Integration, 19 Emory Int'l L. Rev. 1321, 1324 (2005).

${ }^{39}$ See Josh Wingrove and Eric Martin, Canada, Mexico may Keep Nafta Investor Dispute System without U.S, available a $\mathrm{t}<\mathrm{https}: / / \mathrm{www}$. bloomberg.com/news/articles/2018-01-25/canada-mexico-may-keep-naftadispute-resolution-without-u-s> (January 25, 2018).

${ }^{40}$ See United States (U.S.)-Jordan: Agreement Between The United States of America and the Hashemite Kingdom of Jordan on The Establishment of a Free Trade Area, supra n. 10, art. 15.

${ }^{41} I d$. art. 15.3.a.
} 
the environmental effects of the FTA. ${ }^{42}$ The Joint Commission is also authorized to establish and delegate responsibilities to ad hoc and standing committees or working groups, and seek the advice of non-governmental persons or groups. ${ }^{43}$ In summary, the Joint Committee has a vast authority to review all issues pertinent to the US-JO FTA. The Joint Commission does not pose a threat to national sovereignty and there is no danger of too much intervention in markets. The Joint Committee is not supranational body with delegation of power from governments of either the U.S. or Jordan, thereby usurping their functions. The Joint Committee conducts a stock-taking exercise.

Most importantly, for purposes of this article, the Joint Committee plays a conciliatory role in the dispute settlement process, and any consultation to resolve a dispute that arises under the FTA must pass through this committee. ${ }^{44}$ According to the FTA, any dispute that is not resolved through a bilateral consultation may be referred to the Joint Committee. ${ }^{45}$ However, there are several issues that arise concerning the details of the involvement of the Joint Committee in settling the dispute. For example, views of the parties who are members of the Joint Committee may not achieve consensus. Furthermore, the interpretation of the Joint Committee may not conform to the relevant rules of the Vienna Convention on the Law of Treaties. ${ }^{46}$ An interpreter of the US-JO

${ }^{42} I d$. art. 15.2 .

${ }^{43} I d$. art. 15.3.b.

${ }^{44} I d$. art. 15.2.c.

${ }^{45}$ Id. 17.1.b.

${ }^{46}$ The context for the purpose of the interpretation of a treaty shall comprise, in addition to the text, including its preamble and annexes:

(a) any agreement relating to the treaty which was made between all the parties in connexion with the conclusion of the treaty;

(b) any instrument which was made by one or more parties in connexion with the conclusion of the treaty and accepted by the other parties as an instrument related to the treaty.

3. There shall be taken into account, together with the context:

(a) any subsequent agreement between the parties regarding the interpretation of the treaty or the application of its provisions;

(b) any subsequent practice in the application of the treaty which establishes the agreement of the parties 
FTA should analyze the text in honesty, fairness and reasonableness, adopting a literal or textual interpretation of the FTA's words, and in light of the intentions of the FTA's drafters. ${ }^{47}$ These issues are left unanswered in the US-JO FTA.

In over 15 years since the signing of the FTA, the Joint Committee has met regularly. ${ }^{48}$ The Joint Committee has discussed ways to promote bilateral trade and commercial ties including in agricultural trade, customs, labor, and investment promotion, as well as regional and multilateral trade. The Joint Committee has been successful in following up with issues related to the FTA including complaints. ${ }^{49}$

\section{B. Initiating the Dispute Settlement Process}

Consultations provide an opportunity for the parties to gather information and clarify facts. ${ }^{50}$ Consultations also save costs and time by settling disputes amicably rather than referring the matter to dispute panels.

The US-JO FTA parties are required to exert every effort to settle any contentious matter through consultations, which are intended to be cooperative and negotiated in

regarding its interpretation;

(c) any relevant rules of international law applicable in the relations between the parties.

4. A special meaning shall be given to a term if it is established that the parties so intended. Moreover, article 32 is related to the supplementary means of interpretation. It states that recourse may be had to supplementary means of interpretation, including the preparatory work of the treaty and the circumstances of its conclusion, in order to confirm the meaning resulting from the application of article 31 , or to determine the meaning when the interpretation according to article 31 :

(a) leaves the meaning ambiguous or obscure; or

(b) leads to a result which is manifestly absurd or unreasonable.

See Vienna Convention on the Law of Treaties (May 23, 1969), 1155 U.N.T.S. 331, art.31.

${ }^{47} \mathrm{An}$ interpreter is not free to adopt a reading that would result in reducing whole clauses or paragraphs of a treaty to redundancy or inutility. See Appellate Body, Japan-Taxes on Alcoholic Beverages, $\mathrm{WT} / \mathrm{DS} 8 / \mathrm{AB} / \mathrm{R}$, at 12 (Oct. 4, 1996).

${ }^{48}$ See U.S. and Jordan Convene Free Trade Agreement Joint Committee, U.S. Embassy in Amman (May 26, 2016) (The United States and Jordan convened the $7^{\text {th }}$ session of the Joint Committee of the United States-Jordan Free Trade Agreement last Thursday at the Ministry of Industry, Trade and Supply).

${ }^{49}$ See Liza Casabona, U.S. Sends Delegation to Jordan to Discuss Labor Issues (Oct. 1, 2009), available at $<$ https://www.citizenstrade.org/ctc/wpcontent/uploads/2011/05/20091001_senatedelegationtojordan_wwd.pdf $>$.

${ }^{50}$ The US-Bahrain FTA provides that each party shall provide sufficient information in the consultations to enable a full examination of how the matter subject to consultations might affect the operation of the FTA. See US-Bahrain FTA, infra 52, art.19.5.2. 
nature, rather than adversarial and litigious. ${ }^{51}$ At this point no panel actually exists, and, therefore, there is no panel to which a dispute may be referred. Any party can request these consultations. $^{52}$

The scope of consultation is broad enough to cover "any matter" affecting the operation or interpretation of the US-JO FTA ${ }^{53}$ However, the US-JO FTA does not determine whether a consultation request can include both existing and proposed measures.

The FTA provides for a procedural requirement related to the consultation request. In particular, the FTA requires a written consultation request. ${ }^{54}$ The FTA stipulates the elapse of certain period of time - sixty days from submission of consultation requestbefore taking other measures such as referring the matter to the Joint Committee. ${ }^{55}$ In contrast with other FTAs between the U.S. and other Arab countries, the US-JO FTA does not provide accelerated consultation period for cases involving perishable goods. ${ }^{56}$ Perishable goods may include agricultural or fish products that can lose value in short period of time. Therefore, accelerated consultation period is needed.

The US-JO FTA requires that each party affords the other party adequate opportunity for consultations, prompt reply to the request for consultations, and good faith in

\footnotetext{
${ }^{51}$ The parties shall at all times endeavor to agree on the interpretation and application of this Agreement, and shall make every attempt to arrive at mutually satisfactory resolution of any matter that affects the operation of the agreement. United States (U.S.)-Jordan: Agreement Between The United States of America and the Hashemite Kingdom of Jordan on The Establishment of a Free Trade Area, supra n. 10, art. 16.1 .

${ }^{52} I d$. art. 16.2 .

${ }^{53} \mathrm{Id}$.

${ }_{55}^{54}$ Id. art.17.1.b.

${ }^{55} \mathrm{Id}$.

${ }^{56}$ The US-Bahrain FTA provides a 20 day period for consultations in case of perishable goods. See USBahrain FTA, infra note 52, art.19.6. See also US-Morocco FTA, infra note 52, art.20.6. See also USOman FTA, infra note 52, art.20.6.
} 
negotiating. ${ }^{57}$ These requirements are mandated to ensure that each party has the chance to present its views and accommodate a solution within reasonable period of time with open minds to reach such a goal.

\section{Causes of Action}

Article 17 of the FTA provides for a formal dispute settlement mechanism if other methods fail to resolve the matter at issue. The FTA provides the basis of the dispute settlement mechanism and grounds for review. ${ }^{58}$ The FTA provides for the comprehensive coverage of matters that could fall under the dispute settlement mechanism. One party can bring an action against the other if a dispute arises concerning the interpretation of the FTA, either party has failed to carry out its obligations under the FTA, or any party considers measures taken by the other party as severely distorts the balance of trade benefits or substantially undermine fundamental objectives of the agreement. $^{59}$ The determination of whether a party has failed to carry out its obligations under the FTA depends on the judgment of the other party bringing the claim.

\footnotetext{
${ }^{57}$ See United States (U.S.)-Jordan: Agreement Between The United States of America and the Hashemite Kingdom of Jordan on The Establishment of a Free Trade Area, supra n. 10, art. 16.2.

${ }^{58}$ The basis of a dispute under the US-JO FTA is related to the interpretation of the agreement, if either party has failed to carry out its obligations under the agreement, or any party considers measures taken by the other party as severely distorts the balance of trade benefits or substantially undermine fundamental objectives of the agreement. $I d$. art. 17.1.a.

${ }^{59} I d$. art. 17.1.a. The U.S. FTAs with Oman and Morocco include two types of dispute settlement: disputes between parties to the FTAs, and investor-state disputes applicable to claims by an investor of one party against the other party for breach of the FTAs investment obligation. See U.S.-Oman Free Trade Agreement (2006), arts. $10 \& 20.2$, available at $<$

https://ustr.gov/sites/default/files/uploads/agreements/fta/oman/asset_upload_file411_8841.pdf $>$. See also U.S.-Morocco FTA (2004), arts. 10 \& 20.2, available at $<$ https://ustr.gov/sites/default/files/uploads/agreements/fta/morocco/asset_upload_file651_3838.pdf>. Neither the US- JO FTA nor the US-Bahrain FTA contains an investment chapter. See U.S-Bahrain FTA (2006), available at $<$ https://ustr.gov/trade-agreements/free-trade-agreements/bahrain-fta/final-text $>$.
} 
The FTA covers violation and non-violation cases. ${ }^{60}$ In non-violation case, a party can bring a case where the other party takes an action that severely distorts the balance of trade benefits or undermine the fundamental objectives of the FTA. ${ }^{61}$ Even if the one party to the FTA takes an action that is consistent with the letter of the FTA, the other party may still claim that that action is inconsistent with the spirit of the agreement and thus severely distort the balance of trade benefits. Therefore, the non-violation cases broaden the scope of the dispute settlement process. The US-JO FTA non-violation clause intends to protect the opportunities that the FTA provides. It is noticed that the non-violation provision in the US-JO FTA covers all provisions in the FTA. ${ }^{62}$ In other U.S. FTAs with Arab countries, non-violation cases are specified for certain chapters

\footnotetext{
${ }^{60}$ The cause of action known in GATT and WTO parlance as a 'non-violation' complaint alleges the nullification or impairment of any benefit accruing to a Member directly or indirectly under a covered agreement, whether it conflicts with the provisions of a WTO agreement or not. See Matthew Kennedy, WTO Dispute Settlement and the TRIPS Agreement: Applying Intellectual Property Standards in a Trade Law Framework 352- 360 (2016).
}

${ }^{61}$ See United States (U.S.)-Jordan: Agreement Between The United States of America and the Hashemite Kingdom of Jordan on The Establishment of a Free Trade Area, supra n. 10, art. 17.1.a.iii. The language of this article is borrowed from article XXIII.b of GATT 1994. However, article XXIII.b of GATT uses "nullification and impairment" language. Thus, it seems that the GATT language imposes a lower bar since a measure can nullify or impair a benefit though not severely distort the balance of trade benefits. In considering the application of the non-violation provision, it is important to note that it must be interpreted narrowly as set under GATT practice. In order to make a successful claim under the non-violation provision, a FTA party must demonstrate the following elements: (1) taking of a measure by another party, (2) a benefit accruing under the FTA, and (3) sever distortion of the benefit or substantial undermining of the fundamental objectives of the FTA resulting from taking of the measure. The GATT panel in the oilseed case recognized that article XXIII:1(b) serves mainly to protect the balance of tariff concessions. Furthermore, it confirmed that the non-violation nullification or impairment remedy should be approached with caution and treated as an exceptional concept. The panel justified its reasoning on the ground that the idea underlying article XXIII is that the improved competitive opportunities that can legitimately be expected from a tariff concession can be frustrated not only by measures prohibited by the GATT but also by measures consistent with GATT. See GATT Panel Report, European Economic Community-Payments and Subsidies Paid to Processors and Producers of Oilseeds and Related Animal-Feed Proteins, Jan. 25, 1990, GATT B.I.S.D. (37th Supp.) at 86 (1991). Non-violation cases not only covers tariff concessions but also other cases. See GATT Panel Report, United States- Restrictions on the Importation of Sugar and Sugar-Containing Products Applied Under the 1955 Waiver and Under the Headnote to the Schedule of Tariff Concessions, Nov. 7, 1990, GATT B.I.S.D. (37th Supp.) at 228, para. 5.21 (1990).

62 This is similar to the US-Israel FTA. See U.S.-Israel Free Trade Agreement, Apr. 22, 1983, 24 I.L.M. 657, art.19.1.a. 
especially those related to national treatment and market access for goods, rules of origin, government procurement, cross-border trade in service, and intellectual property. ${ }^{63}$

Unlike other U.S. FTAs which included provisions on antidumping and countervailing duties, antidumping and countervailing are excluded implicitly from the coverage of the US-JO FTA. ${ }^{64}$ This could be interpreted that the U.S. did not want to subject its disciplines on antidumping or countervailing duties to scrutiny of a panel under the FTA. In other words, the U.S. did not want a binational panel to replace domestic courts examining antidumping or countervailing determinations. The only trade remedy provision found in the US-JO FTA is related only to safeguard measures. ${ }^{65}$ However, safeguard measures are intended to address import surge as a result of tariff elimination but not to address injury to domestic industry. In this case, antidumping and countervailing become shelter for import competition.

\footnotetext{
${ }^{63}$ See US-Bahrain FTA, supra note 52, art.19.2.c. See US-Oman FTA, supra note 52, art.20.2.c. See also US-Morocco FTA, supra note 52, art.20.2.c.

${ }^{64}$ Chapter nineteen of the US-Canada FTA provides for an unprecedented binational dispute settlement panel in antidumping and countervailing duty cases. The panel will apply each country's antidumping and countervailing laws. See Rebecca A. Sanford, The Canada-U.S. Free Trade Agreement: Its Aspects, Highlights, and Probable Impact on Future Bilateral Trade and Trading Agreements, 7 Penn State International Law Review 371, 375 (1989). In the North American Free Trade Agreement (NAFTA), some chapters contain their own dispute resolution processes. Chapter 19 of NAFTA is dealing with antidumping and countervailing duty disputes. Chapter 19 of NAFTA establishes binational panels to review final determinations of antidumping and countervailing duty measures imposed under NAFTA parties' national antidumping and countervailing duty law. For discussion of NAFTA's dispute resolution processes under other than chapter 20 procedure see David S. Huntington, Settling Disputes Under the North American Free Trade Agreement, 43 HARV.INT'L L. J. 407, 430-436 (1993). See also David A. Gantz, The United States and NAFTA Dispute Settlement: Ambivalence, Frustration and Occasional Defiance (University of Arizona James E. Rogers College of Law, Discussion Paper No. 06-26 (2006).

${ }^{65}$ See US-JO FTA, United States (U.S.)-Jordan: Agreement Between The United States of America and the Hashemite Kingdom of Jordan on The Establishment of a Free Trade Area, supra n. 10, art. 10. The USIsrael, US-Bahrain, and US-Morocco FTAs do not have specific provisions regarding antidumping and countervailing duties. Chapter eight of Chile-US FTA and Dominican Republic-Central American-US FTA reaffirm that each Party retains its WTO rights and obligations with regard to the application of antidumping and countervailing duties. The Chile-US FTA and Dominican Republic-Central American-US FTA also specify expressly that there are no rights or obligations created with respect to these measures, including recourse to dispute settlement procedures, under the respective FTAs.
} 
The US-JO FTA is silent regarding bilateral consultation or action on proposed legislations. By contrast, other U.S. FTAs with Arab countries provide explicitly that neither party can refer a matter concerning a "proposed measure" to a dispute settlement panel. ${ }^{66}$ In other words, these U.S. FTAs with Arab countries -excluding Jordan- do not accommodate requests for dispute panel regarding pending legislation in a partner country that is inconsistent with the FTA. The importance of excluding a "proposed measure" from the coverage of dispute settlement cannot be overstated. If such a "proposed measure" is entertained, this can lead to waste of resources for panels to consider measures that may never be enacted. ${ }^{67}$

\section{Establishment of a Panel and its Procedures}

When bilateral consultations are exhausted, the matter is referred to the Joint Committee. Referring the matter to the Joint Committee provides the parties with another chance to negotiate and settle the matter. If the FTA Joint Committee does not resolve the dispute within ninety days, either party may refer the matter to an ad hoc dispute settlement panel. ${ }^{68}$ The system adopted by the US-JO FTA is quasi-judicial because it involves bilateral consultations within the Joint Committee and panels. ${ }^{69}$ In other words, the US-JO FTA adopted a hybrid system.

The panel consists of three members. ${ }^{70}$ Each party appoints one member. ${ }^{71}$ The remaining panelist- who serves as chairman- shall be selected by the mutual agreement of

\footnotetext{
${ }^{66}$ See US-Bahrain FTA, supra note 52, art.19.7.2. See US-Morocco FTA, supra note 52, art.20.7.2. See also US-Oman FTA, supra note 52, art.20.7.2.

${ }^{67}$ See Victoria Donaldson and Simon Lester, Dispute Settlement 385, in Bilateral and Regional Trade Agreements: Commentary and Analysis (Simon Lester and Brian Mercurio eds. 2009).

${ }^{68}$ See United States (U.S.)-Jordan: Agreement Between The United States of America and the Hashemite Kingdom of Jordan on The Establishment of a Free Trade Area, supra n. 10, art. 17.1.c.

${ }^{69}$ Id. arts. 17.1.b \& c.

${ }^{70} I d$. art. 17.1.c.

${ }^{71} \mathrm{Id}$.
} 
the panelists already appointed. Thus, the disputing parties in the FTA cannot select the third panelist.

The FTA does not require notice to establish such a panel. The FTA does not prescribe a time limit within which the panel should be called or what happens in the case whereby the parties do not agree on the panel's membership. ${ }^{72}$ According to the FTA, within 180 days of the entry into force of the FTA the parties should develop rules for the selection and conduct of the members of the panel and model rules of procedure for such panels. ${ }^{73}$ To date, no such rules were issued. By creating these rules, the FTA parties can determine the qualifications, expertise, nationality, and remuneration for panelists serving on a panel. ${ }^{74}$ Model rules of procedures may include policies, practices, and procedures for language(s) used, receiving initial and rebuttal written submissions, confidentiality of information, seeking information from different sources, and how oral hearings will be conducted before a panel. ${ }^{75}$

The US-JO FTA leaves many questions unanswered. For example, how large the panel roster, if any, in the US-JO FTA should be ${ }^{76}$ How long should the panelist serve on the list? Should a panelist be full-time or part-time? Can private lawyer represent the

\footnotetext{
${ }^{72}$ The US-Israel FTA stipulates a time limit of forty-five days from the date of referral to establish a panel. See U.S.-Israel Free Trade Agreement, supra note 55, art. 19.1.d. Panel selection can take significant time. See David Gantz, The United States and NAFTA Dispute Settlement: Ambivalence, Frustration and Occasional Defiance, Arizona Legal Studies Discussion Paper 06-16, 13-15 (2009).

${ }^{73}$ See United States (U.S.)-Jordan: Agreement Between The United States of America and the Hashemite Kingdom of Jordan on The Establishment of a Free Trade Area, supra n. 10, art. 17.3.

${ }^{74}$ See Joost Pauwelyn, WTO Panelists are from Mars, ICSID Arbitrators are from Venus: Why? And Does it Matter? 7 (2015), available at < http://www.iilj.org/wpcontent/uploads/2016/09/PaulwelynIILJColloq2015.pdf > (last visited Dec. 25, 2017).

${ }^{75}$ Later U.S FTAs with Arab countries provide such policies. See US-Morocco FTA, supra note 52, art.20.8. See also US-Bahrain FTA, supra note 52, art.20.8. See also US-Bahrain FTA, supra note 52, art.19.8.

${ }^{76}$ The US-Morocco FTA establishes a reserve list of eight individuals who are willing and able to serve as panelists. Those individuals must be chosen strictly on the basis of objectivity, reliability, and sound judgment and have expertise or experience in law, international trade, or the resolution of disputes arising under international trade agreements. See US-Morocco FTA, supra note 52, art.20.7.5. See also US-Oman FTA, supra note 52, art.20.7.4.
} 
government of Jordan in a dispute under the FTA or should he/she be a governmental

lawyer? How many oral hearing(s) or written submission(s) each disputing party will be given as a due process mechanism?

\section{Panel's Report}

Under the US-JO FTA there is only one final report. The US-JO FTA does not require that the panel issues an initial report on which both parties can comment on, as the case under the WTO. ${ }^{77}$ Therefore, under the US-JO FTA, the panel issues one final report. The FTA contains no specific provision on the method by which the panel is to render its report i.e. consensus or majority. This is presumably linked to the fact that model rules of procedure need to be developed. Further, it is unclear what the official language of the panel report is. The panel report might be in two copies, English and Arabic, which mean additional administrative and financial costs in drafting.

The panel's report shall include "findings of facts" and a "determination" as to whether either party has failed to carry out its obligations under the FTA or a measure taken by either party severely distorts the balance of trade benefits or substantially undermines the fundamental objectives of the FTA. ${ }^{78}$ If the panel finds that a party has failed to carry out its obligations under the US-JO FTA, it may, at the request of the

\footnotetext{
${ }^{77}$ It is unfortunate setback that the US-JO FTA does not require an interim report issued by the panel and submitted to the parties for comments before it issues a final report. It is important to issue an interim report because the panel would prevent the parties from coming backing and accuse the panel of misstating their arguments, ignoring their point of view, substantive omissions, technical errors, or denying them the right to present their argument. Therefore, the panel by issuing an interim report would give the parties once and for all the last chance to present their comments. See Steve Charnovitz, Transparency and Participation in the World Trade Organization, 56 Rutgers L. Rev. 927, 940 (2004). The US-Oman FTA and US-Morocco FTA require the panels to issue an initial report and afford the opportunity to the parties to provide comments. See US-Oman FTA, supra note 52, art.20.9.3. See also US-Morocco FTA, supra note 52, art.20.9.3.

${ }^{78}$ See United States (U.S.)-Jordan: Agreement Between The United States of America and the Hashemite Kingdom of Jordan on The Establishment of a Free Trade Area, supra n. 10, art. 17.1.d.
} 
parties, make recommendations for resolution of the dispute. ${ }^{79}$ The authority of the panel to make recommendations is qualified by request of both parties. In addition, the ability for the panel to make recommendations is limited to the instance whereby either party has failed to carry out its obligations under the FTA. The ability to make recommendations is not available in other instances i.e. measure taken severely distorts the balance of trade benefits or substantially undermining the fundamental objectives of the FTA. Where the panel is set to make recommendations, the FTA does not provide guidelines for the types of recommendation. The usual recommendation in this case would be to eliminate the non-conformity.

Although the panel's report includes "findings of facts" and a "determination", nevertheless the US-JO FTA does not attend to the essential element of the report i.e. reasoning. In other words, the FTA does not require the panel to detail the reasons for its conclusions. ${ }^{80}$ It might be understandable that, in certain cases, a comprehensive presentation of the Panel's factual findings could make its conclusions reasonable. However, other cases could necessitate for the panel to validate its report with convincing reasons.

As the death knell to the legality of the panel process, the panel report is not binding. ${ }^{81}$ And, while one can speculate, one does not know, and perhaps would have

\footnotetext{
${ }^{79} I d$. art. 17.1.d.

${ }^{80}$ See Gregory Shaffer, Manfred Elsig, Sergio Puig, The Extensive (but Fragile) Authority of the WTO Appellate Body, 79 Law and Contemporary Problems 238, 252-253 (2016) (The AB often adopted a technical, formalistic, and text-based approach, frequently citing dictionaries to support its reasoning. By wrapping their rulings in textual and technical reasoning and consensus decisions, the $\mathrm{AB}$ members enhance their authority as upholders of the law. The $\mathrm{AB}$ routinely and at times harshly overruled panels for deficiencies in their legal reasoning or their application of treaty interpretation techniques).

${ }^{81}$ This does not mean that the panel is ineffective, since even if its decision is considered legally binding either party may never comply. Both parties may comply with the panel's decision because they want to avoid a reputation of being a rule breaker especially after a decision by neutral panel is made public. See
} 
difficulty to learn, the rationale for the U.S. to change from legality in the WTO, which it fought hardly for, to diplomacy in the FTA. ${ }^{82}$ The panel's report functions as conciliatory report. Therefore, the US-JO FTA panel is not supranational body.

The non-binding nature of a panel report creates its own set of unresolved questions. In particular, the non-binding panel report clashes with the forum-shopping provision in the US-JO FTA. ${ }^{83}$ If the language of the forum-shopping provision is interpreted narrowly, the U.S. or Jordan is forbidden from resorting to a binding dispute resolution mechanism. At the end of the other spectrum, the U.S. or Jordan can invoke any dispute resolution mechanism under similar international agreements.

The FTA requires the Joint Committee to resolve the dispute taken into account the panel report, as appropriate. ${ }^{84}$ This means that in most cases, the panel report will be taken into account. The panel decision represents an objective and articulate decision that would help resolve the dispute. Hence, it should be taken into account, otherwise the whole FTA would be at risk through non-compliance with panel decisions. Moreover, due to the publicity of the panel decision, the Joint Committee will face a pressure to

United States (U.S.)-Jordan: Agreement Between The United States of America and the Hashemite Kingdom of Jordan on The Establishment of a Free Trade Area, supra n. 10, art. 17.1.d.

${ }^{82}$ Perhaps, the U.S. considered that in no way increase imports from Jordan would lead to trade disputes. In other words, the fact that the parties to the FTA are remote geographically or engaged in less trade merited the U.S. to sway from judicialized dispute settlement mechanism. Another speculation is that the U.S. feared that one time it might a respondent in a case rather than a complainant. On other hand, one can expect that Jordan, the weaker party, preferred a legalistic approach to preserve its rights in case of a violation. On other hand, one can expect that Jordan, the weaker party, preferred a legalistic approach to preserve its rights in case of a violation. See Michael Reisman and Mark Wiedman, Contextual Imperatives of Dispute Resolution Mechanisms: Some Hypotheses and Their Application in the Uruguay Round and NAFTA, 29.3 Journal of World Trade 5, 9 (1995) (developing countries prefer rule-based dispute settlement that as they lack international economic, political and legal influence).

${ }^{83}$ The US-Jo FTA provides that if a panel under FTA or any other applicable international dispute settlement mechanism has been invoked by either Party with respect to any matter, the mechanism invoked shall have exclusive jurisdiction over that matter. See United States (U.S.)-Jordan: Agreement Between The United States of America and the Hashemite Kingdom of Jordan on The Establishment of a Free Trade Area, supra n. 10, art. 17.1.e.1.

${ }^{84} I d$. art. 17.2.a. 
comply or take the report into account. Also, the publication of the panel's report may generate sympathy that would pressure the opposing party to comply with the ruling risking rending the whole FTA ineffective. It will create guidance for future trade disputes.

The US-JO FTA fails to provide a process for appeal or review along the lines of the WTO's standing Appellate Body. The WTO's Appellate Body may be important in terms of assuring both consistency and fairness in a rule-based adjudicatory process. ${ }^{85}$ However, since the decision of a US-FTA panel is not binding there is no need for appeal.

\section{Implementation of Panel Report}

Even if the panel makes it report, still the ultimate forum for resolving the dispute is through the Joint Committee. Once the final report is provided to the parties, the Joint Committee endeavors to resolve the dispute taking the report of the panel into account as appropriate. $^{86}$

If the Joint Committee does not resolve the dispute, within thirty days from the date the panel presented its report, the affected party is entitled to take any "appropriate" and "commensurate" measure. ${ }^{87}$ It is notable that the FTA is absent any requirement on reporting of compliance or monitoring. The FTA establishes the right to take countermeasures unilaterally, without the authorization of the Joint Committee. On other hand, for example, the right to retaliate under WTO rules is subject to the approval of the

\footnotetext{
${ }^{85}$ See Mark Huber and Greg Tereposky, The WTO Appellate Body: Viability as a Model for an InvestorState Dispute Settlement Appellate Mechanism, 32.3 ICSID Review - Foreign Investment Law Journal 545, 560-562 (2017).

${ }^{86}$ See United States (U.S.)-Jordan: Agreement Between The United States of America and the Hashemite Kingdom of Jordan on The Establishment of a Free Trade Area, supra n. 10, art. 17.2.a.

${ }^{87}$ Id. art. 17.2.b. By contrast, the US-Morocco and US-Oman FTAs require the parties to enter into negotiations with a view to developing mutually acceptable compensation. See US-Morocco FTA, supra note 52, art.20.11.1. See also US-Oman FTA, supra note 52, art.20.11.1.
} 
DSB. ${ }^{88}$ However, the right to take countermeasures, under the US-JO FTA, is contingent upon exhaustion of consultations, panel procedures, and Joint Committee deliberations.

The use of the term "commensurate" and "appropriate" emphasizes that the measure taken must be in proportion to the violation. ${ }^{89}$ The US-JO FTA does not provide guidance as to the meaning of "appropriate and commensurate" measures. Moreover, the US-JO FTA does not determine if the "appropriate and commensurate" measures must be in the same sector as affected by the measure or can extend to other sectors. In some cases, taking "appropriate and commensurate" measures in the same sector affected by the measure may not be plausible.

The US-JO FTA does not specify the case where the losing party believes that the "appropriate" and "commensurate" measure taken is excessive. It seems logical, in this scenario, for the losing party to request the same dispute settlement panel to convene to determine the level of the measure. However, any review of the measures' level comes after the fact. In other words, the review of the measures' level comes after the measure has actually been applied.

In theory, the dispute settlement process under the US-JO FTA takes approximately nine months to conclude. ${ }^{90}$ The table below shows the timeline of the dispute settlement process.

\footnotetext{
${ }^{88}$ See Cherie O’Neal Taylor, Beyond Retaliation, 38 Nw. J. Int'l L. \& Bus. 55, 64-65 (2017).

${ }^{89}$ The use of these terms in the US-JO FTA is in contrast with the language used by the WTO whereby the level of suspension of concessions shall be equivalent to the level of nullification or impairment. Id. at 113 .

${ }^{90}$ It is not unusual for specific dispute settlement process deadlines to be disregarded in certain cases for many factors such as the significance of the case, political ramification, and lack of resources to draft panel reports on time. See James C. Hartigan (ed.), Trade Disputes and the Trade Dispute Settlement Understanding of the WTO: An Interdisciplinary Assessment 3, 139 (2009). See also Claus-Dieter Ehlermann, The Workload of the WTO Appellate Body: Problems and Remedies, 20.3 Journal of International Economic Law 705, 713 (2017).
} 


\begin{tabular}{|ll}
\hline 60 days & Bilateral Consultations \\
90 days & Joint Committee Consultations (extend or shorten this period) \\
90 days & Panel Report \\
30 days & Joint Committee Endeavor after Panel Report \\
No Time Limit & Appropriate and Commensurate Measure \\
\hline
\end{tabular}

\section{Transparency}

The FTA has a side understanding on transparency in the dispute settlement mechanism. ${ }^{91}$ The FTA requires the publication of parties' written submissions. ${ }^{92}$ The FTA also requires the oral hearings of the parties be open to the public. By opening the dispute settlement process to the public, the US-JO FTA opened the closed doors of panel chambers to the public and uncovered the veil of secrecy. ${ }^{93}$ Publication of a panel's report is essential for securing the compliance of the losing party. Publication of the report makes it possible for the winning party- even if that party is much smaller and weaker than the losing party- to create public opinion among other countries.

The FTA allows for acceptance and consideration of amicus curia briefs. ${ }^{94}$ Under the US-JO FTA, a panel is "obliged" to accept and consider amicus curia of whatever

\footnotetext{
${ }^{91}$ See Memorandum of Understanding on Transparency in Dispute Settlement under the Agreement between the United States and Jordan on the Establishment of a Free Trade Area at $<$ http://www.ustr.gov/regions/eu-med/middleeast/memodis.pdf $>$.

${ }_{92}$ Para. 2.a. Id. See US-Morocco FTA, supra note 52, art.20.8.c. See also US-Bahrain FTA, supra note 52, art.19.8.c. See also US-Oman FTA, supra note 52, art.20.8.c.

${ }_{93}$ The US-Israel FTA does not provide for the publication of the panel's report. See U.S.-Israel Free Trade Agreement, supra note 55, art. 19.

${ }^{94}$ For more on amicus curiae see Padideh Ala'i, Judicial Lobbying At the WTO: The Debate over the Use of Amicus Curiae Briefs and the U.S. Experience, 24 FORDHAM INT'L L.J. 62, 67, 84, 86 (2000) (stating that the solitary support of the U.S. for amicus curiae submissions before the WTO Appellate Body can be attributed to the U.S. legal system's historical familiarity with the institution of amicus curiae and its evolution from "friend of the court" to a "judicial lobbyist" within the U.S. Supreme Court jurisprudence. The function of amicus curiae at common law was one of oral shepardizing or the bringing up of cases not known to the judge. The amicus curiae first appeared on the U.S. scene in 1821 in Green v. Biddle case).
} 
type filed by individuals, legal persons, and non-governmental organizations. ${ }^{95}$ Thus, accepting amicus curiae brief is mandated under the understanding no matter what type this brief is or whether it addresses factual or legal information. The only qualification for amicus curia submissions is the fact that these non-governmental organizations must have interest in the outcome of the dispute. ${ }^{96}$ There are no further details required for amicus curia submissions such as declaring source of funding, nature of nongovernmental organizations' activities, time limits for submissions, size and content of submissions, and how such submissions would add value to the knowledge of the panel. At any rate, considering and accepting amicus curiae brief $\mathrm{n}$ the panel proceedings will add complexity to the panel process.

\section{Forum Shopping}

The US-JO FTA determines the litigating forum for a dispute. ${ }^{97}$ The U.S. or Jordan can forum shop a dispute mechanism of their choice to resolve the dispute with an exclusionary clause. Once either party invokes dispute settlement mechanism of certain forum this will function to exclude that party from invoking the same subject matter before another forum. For example, the U.S. or Jordan can resort to the WTO dispute settlement mechanism to resolve their dispute rather than to the dispute settlement mechanism under the US-JO FTA.

\footnotetext{
${ }^{95}$ See Memorandum of Understanding on Transparency in Dispute Settlement under the Agreement between the United States and Jordan on the Establishment of a Free Trade Area, supra n. 42, para. 2.c. ${ }^{96} I d$.

${ }^{97}$ The US-JO FTA states that if the dispute settlement panel under the agreement or any other applicable international dispute settlement mechanism has been invoked by either Party with respect to any matter, the mechanism invoked shall have exclusive jurisdiction over that matter. See United States (U.S.)-Jordan: Agreement Between The United States of America and the Hashemite Kingdom of Jordan on The Establishment of a Free Trade Area, supra n. 10, art. 17.1.e.1.
} 
In the US-JO FTA, priority is given to the dispute settlement procedures under the WTO in certain cases. These cases involve services and intellectual property ${ }^{98}$ In other words, disputes regarding trade in services and intellectual property can be referable to the panel procedures under that FTA only if they are not subject to resolution under the WTO dispute settlement mechanism.

Choosing such a forum is limited to the extent that the "subject matter" of the dispute is covered by both the US-JO FTA and the WTO Agreements. In other words, if Jordan fails to carry out its obligation under the e-commerce provision, the U.S. might not be able to refer the matter to the WTO since the WTO agreements, as of this date, do not cover e-commerce. ${ }^{99}$ This is supported by subparagraph $4 . \mathrm{b}$ of article 17 of the US-JO FTA allows a party to invoke the panel procedures for claim regarding intellectual property rights to extent that such a claim is not covered under the DSU of the WTO.

The forum shopping opportunity seems to define more clearly the right of a party to recourse to US-JO FTA forum or other fora. However, in practice, the forum shopping provisions may give rise to many problems. For instance, there could be disagreement over Jordan's choice of forum, or the decision of a panel under the US-JO FTA could differ from that reached under the WTO. ${ }^{100}$

\footnotetext{
${ }^{98}$ Subparagraph 17.4.a of the FTA provides "A Party may invoke a panel under paragraph 1.c of this Article for claims arising under Article 3 [services] only to the extent that a claim arises with regard to a commitment that is inscribed in the Party's Services Schedule to Annex 3.1 to this Agreement, but is not inscribed in the Party's Schedule of specific commitments annexed to GATS. Such commitment may include a market access or national treatment commitment in a sector, a horizontal commitment applicable to a sector, or additional commitment". Additionally, subparagraph 17.4.b provides "Except as otherwise agreed by the Parties, a Party may invoke a panel under paragraph 1.c of this Article for claims arising under Article 4 [intellectual property] only to the extent that the same claim would not be subject to resolution through the WTO Understanding on Rules and Procedures Governing the Settlement of Disputes".

${ }^{99}$ If a dispute settlement mechanism under the FTA or other forum failed for "procedural" or "jurisdictional" reasons, this shall not prevent either party from invoking the other forum. Id. art. 17.1.e.ii. ${ }^{100}$ See Marc L. Busch, Overlapping Institutions, Forum Shopping, and Dispute Settlement in International Trade, 61 International Organization 735 738-740 (2007).
} 


\section{Private Actions}

The US-JO FTA dispute resolution mechanism provides standing solely to the parties. Private actions against another party on the grounds that a measure of another party is inconsistent with the FTA are prohibited. ${ }^{101}$ This reflects long-standing U.S. policy and language found in legislation that approves trade agreements. ${ }^{102}$ By contrast, foreign investors can initiate claims against the host government. ${ }^{103}$ These claims cover wide range of actions or inactions such as measures relating to taxation, environmental regulation, among other issues.

Even though the US-JO FTA was concluded for the benefit of manufacturers and entrepreneurs, the agreement does not provide private right of action. This means that manufacturers and importers alike cannot rely on their respective governments to initiate dispute resolution proceedings under the US-JO FTA.

The private right of action in US-JO FTA is significant for Jordan. Jordan follows the monist system, in which treaties are fully self-executing whereby which once approved and in force, treaties automatically have direct applicability by government agencies, courts, and private parties, even where they create conflicts with existing legislations. ${ }^{104}$ Trade agreements in Jordan are automatically the law of the land. Thus,

${ }^{101}$ See United States (U.S.)-Jordan: Agreement Between The United States of America and the Hashemite Kingdom of Jordan on The Establishment of a Free Trade Area, supra n. 10, art. 18.1.

${ }^{102}$ See Nohl Patrick Bryant, Private Rights of Action Under Free Trade Agreement Implementation Acts, LLM Thesis, The George Washington University Law School 20-28 (2013).

${ }^{103}$ See David R. Haigh, Chapter 11--Private Party vs. Governments, Investor-State Dispute Settlement: Frankenstein or Safety Valve, 26 Can.-U.S. L.J. 115, 116-118 (2000).

${ }^{104}$ The monist theory asserts that domestic and international law are two components of a single body of knowledge called law. the main features of this theory are the unity of the international and domestic law, the automatic incorporation of international law into domestic law, and the supremacy of international law over domestic law in cases of conflict between the two. Dualists regard international law and domestic law as two completely different systems of law. The result of this is that international human rights norms ratified by dualist states are not enforceable until they have been incorporated or transformed into domestic law. See Martin Dixon, Textbook on International Law 64-70 (2013). Israel case law is inspired by the U.S. dualist approach. See Ruth Lapidoth, International Law Within The Israeli Legal System, 24 IS. L. R. 451, 
trade agreements could be the basis of private citizen actions charging the government with failing to implement the agreements unless there are provisions in these trade agreements excluding such legal actions.

\section{Special Rules for Labor and Environmental Disputes}

For the first time in U.S. trade history, the US-JO FTA included provisions that address environment and labor in the main text of the agreement. ${ }^{105}$ While the US-JO FTA includes specific references to environment in various different articles, articles 5 and 6 are the main environmental provision. ${ }^{106}$ The US-JO FTA mandates that each party shall strive not to waive or derogate from environmental and labor laws as an encouragement of trade with each other and to provide high levels of environmental and labor protection. ${ }^{107}$

The panel's jurisdiction over labor and environmental issues is narrower than other actions inconsistent with the US-JO FTA. Not every failure to enforce environmental or labor law constitutes grounds for initiating dispute settlement. Rather, the obligation is as

458-460 (1990) (The Israeli Supreme Court declared the dualist nature of the Israeli legal system in the case of Custodian of Absentee Property v. Samarah et al of 1956 in which the respondents tried to rely on the General Armistice Agreement between Israel and Jordan of 1949 to claim certain rights to property. The Court stated that such a treaty is no way within the jurisdiction of the courts in Israel unless and to the extent the treaty or the rights and obligations it entails have gone through "the melting pot" of the legislation of Israel and have assumed the form of binding law).

${ }_{105}$ NAFTA contains environmental protection provisions in a side agreement, known as the North American Agreement on Environmental Cooperation (NAAEC). See Howard Mann, NAFTA and the Environment: Lessons for the Future, 13 Tul. Envt. L.J. 387, 409 (2000) (suggesting that the impact of trade agreements on sustainable development requires that the environment be treated as an issue that is "over here", inside the agreement, not "over there" in another agreement). See also Jerome Levinson, Certifying International Worker Rights: A Practical Alternative, 20 Comp. Lab. L. \& Policy 401, 405 (1999) (arguing that incorporating worker rights into the main body of multilateral agreements has reached a dead end. The only path to progress now is unilateral actions on the part of the U.S. The more effective way is to resort to aggressive unilateral action).

${ }^{106}$ For example, the U.S. and Jordan may exclude from patentability certain inventions to avoid prejudice to the environment. Additionally, the FTA incorporates by reference article XX of GATT 1994 including environmental measures necessary to protect human, animal or plant life or health and measures relating to the conservation of "living and non-living" exhaustible natural resources. See United States (U.S.)-Jordan: Agreement Between The United States of America and the Hashemite Kingdom of Jordan on The Establishment of a Free Trade Area, supra n. 10, arts. $4.18 \& 12.1$.

${ }^{107} I d$. arts. $5.1 \& 5.2,6.1 \& 6.2$. 
follows: A Party shall not fail to effectively enforce its environmental and labor laws through a "sustained or recurring course of action or inaction in a manner affecting trade". ${ }^{108}$ Thus, the dispute settlement provisions can be invoked only if party's own environmental or labor laws are not be enforced rather than whether they meet international standards.

The US-JO FTA provides a two-prong test. This test requires a "sustained or recurring course of action or inaction" in a manner affecting trade between the parties. The FTA does not define the terms "sustained or recurring." Although "sustained or recurring" implies something that happens more than one time, the definition may not be settled so easily. The second-prong of the test requires that the sustained action/inaction be in a manner that affects trade. This prong determines what violation is actionable or non-actionable. Only sustained action or inaction that "affects" trade is actionable. The second-prong of the test ensures that environmental obligations are linked to trade in a manner that would otherwise be considered an intrusion into the domestic arena of the FTA parties.

The U.S.-JO FTA establishes a single dispute settlement mechanism for all disputes under the agreement. ${ }^{109}$ Parties to the U.S.-JO FTA can arguably impose trade sanctions for failure to enforce environmental or labor protection. To ease concerns regarding imposing trade sanctions for environmental violations, the U.S. and Jordan exchange side letters, whereby both parties expressed their intention not to exercise trade sanctions for

\footnotetext{
${ }^{108} I d$. art. 5.3.a.

109 The US-Oman FTA requires that panelists have expertise in labor or environmental matter. See USOman FTA, supra note 52, art. 27.4.c.
} 
these violations. ${ }^{110}$ Insulating labor and environmental violations from trade sanctions was one of the more controversial aspects of the US-JO FTA. ${ }^{111}$ The exchange of letters paved the way for the Congress's approval of the FTA with Jordan.

In 2006, the U.S. complained about worker's rights in Jordan and requested consultations regarding the failure to investigate alleged labor abuses and failure to protect workers. ${ }^{112}$ Extensive meetings were held with Jordanian government officials, representatives from labor unions and worker rights advocates as well as business groups. ${ }^{113}$ The U.S and Jordan started a Better Work program to observe workers' conditions in Jordan.

The U.S. FTAs with Oman, Bahrain, and Morocco follow the same standards and procedures as the US-JO FTA. However, these former FTAs impose fines -capped at US $\$ 15$ million as adjusted for inflation- in case of violation. ${ }^{114}$ Fines are collected through suspension of concessions, if necessary, and are spent on labor or environmental initiatives in the territory of the party complained against.

\footnotetext{
${ }^{110}$ On July 23, 2001, former USTR Robert Zoellick and Jordan's ambassador to the U.S. exchanged letters. These identical letters pledged to resolve any differences that might arise between the two countries under the agreement, without recourse to formal dispute settlement procedures. They also specified that each government "would not expect or intend to apply the Agreement's dispute settlement enforcement procedures ... in a manner that results in blocking trade. See USTR, Side Letters, available at $<$ https://ustr.gov/trade-agreements/free-trade-agreements/jordan-fta/final-text > (last visited January 15, 2018).

${ }^{111}$ During the Senate debate, Senator Phil Gramm warned that he will oppose any effort to turn the US-JO FTA into a model for how future trade agreements should deal with environmental and labor rights. See Grary G. Yerkey, USTR Says Bush Administration Supports U.S.-Jordan Free Trade Agreement "as it is," 18 Intl. Trade Rep. (BNA) 1013 (June 28, 2001) (Sen. Grassley suggested attaching "side letters" to the agreement in which the United States and Jordan promise not to use sanctions to enforce labor and environmental provisions of the accord). See also Nancy Ognanovich, Bush Tells Abdullah He Will Push Hill to Adopt Jordan Free-Trade Agreement, 18 Intl. Trade Rep. (BNA) 632 (Apr. 19,2001 ) (Jordanians indicated that they are going to leave that [specifics of environmental and labor provisions] to the [U.S.] administration to work with Congress directly).

${ }^{112}$ See Steven Greenhouse and Michael Barbaro, An Ugly Side of Free Trade: Sweatshops in Jordan, New York Times (May 3, 2006).

${ }^{113}$ See USTR, Jordan Free Trade Agreement, available at $<$ https://ustr.gov/trade-agreements/free-tradeagreements/jordan-fta> .

${ }^{114}$ See US-Bahrain FTA, supra note 52, Annex 19.A. See also US-Morocco FTA, supra note 52, Annex 20.A. See also US-Oman FTA, supra note 52, Annex 20.A.
} 


\section{Assessment of Dispute Settlement Mechanism under US-JO FTA}

The procedures of dispute settlement under the US-JO FTA, though contains some improvements than the US-Israel FTA, to some extent does not offer potent means for resolving disputes such as that of the WTO. The US-JO FTA is akin, more or less, to the early years of the GATT 1994 where diplomacy ruled over legality. ${ }^{115}$ The US-JO FTA's dispute settlement mechanism should have been strengthened since it will serve as a model for the proposed US-Middle East FTA. ${ }^{116}$ The latter FTA should provide a framework for the establishment of a detailed potent and comprehensive dispute settlement mechanism.

It is difficult to evaluate the effectiveness of the dispute settlement mechanism under the US-JO FTA, since data is absent to show how many disputes were settled through consultations, brought before panels, or withdrawn. ${ }^{117}$ This hints that the dispute system of the US-JO FTA is non-or under-utilized. Therefore, development of the US-JO FTA

\footnotetext{
115 There was a view that dispute settlement under the GATT should be a natural consequence of the negotiation process. Some countries highlighted the ambiguity of GATT rules, the political sensitivity of trade disputes, and the complex trade-offs of competing interests that go into the formulation of any trade rule. Thus, they argued that GATT dispute resolution should not be formal, legal, or adjudicatory. See David K. Tarullo, Logic, Myth and International Economic Order, 26 HARV. INT'L L. J. 533 (1985). Other countries, such as the U.S., viewed the dispute system under the GATT as rule-based system in which violations are exposed and subject to sanctions. In the U.S. view, GATT rules will become clearer and predictable if GATT dispute resolution is characterized by rule-based decisions rendered through an adjudicatory dispute resolution process, will increase compliance with GATT standards, and will alleviate protectionist pressures. See JOHN H. JACKSON ET AL., LEGAL PROBLEMS OF INTERNATIONAL ECONOMIC RELATION 339 (1995).

${ }^{116}$ President Bush announced the U.S. intent to launch a 10-year effort to form a US-Middle East free trade area. See Mike Allen \& Karen DeYoung, Bush Calls Trade Key To Mideast; President launches Plan For U.S. Pact in Region, Wash. Post, May 10, 2003, at A01. See also Grary G. Yerkey, President Bush Lays Out Broad Plan for Regional FTA with Middle East by 2013, 20 Int'l. Trade Rep. (BNA) 856 (May. 15, 2003) (stating that the U.S. will employ a "building-block" approach. This approach requires, as a first step, a Middle East country to accede to the WTO or concluding Trade and Investment Framework Agreement(s) ("TIFA"). Afterward, the U.S. will negotiate FTA with individual countries. Finally, preferably before 2013, a critical mass of bilateral FTAs would come together to form the broader USMiddle East FTA). See also Bessma Momani, A Middle East Free Trade Area: Economic Interdependence and Peace Considered, 30 The World Economy 1682, 1686 (2007). Until now, the proposal of US-Middle East FTA has not materialized.

${ }^{117}$ WTO panel reports are always published. See WTO, Dispute Settlement- Disputes by Members < https://www.wto.org/english/tratop_e/dispu_e/dispu_by_country_e.htm > (last visited Jan. 10, 2018).
} 
jurisprudence is lacking and there are no precedents to which the parties in the future will observe. Difficulties in the interpretation and application of the FTA would ultimately arise. However, despite the fact that the dispute settlement provisions under the US-JO FTA represent to some degree an interesting language, it is doubtful that they will be used. ${ }^{118}$ The U.S. would not like to be described as a bully against a small country like Jordan and would find it difficult to justify such appropriate and commensurate action vis-à-vis the international trade society at large.

Frequency of trade disputes between the U.S. and Jordan are associated with economic size and trade share. ${ }^{119}$ Another reason that may explain the non-existence of dispute settlement panels under the US-JO FTA is the fact that the WTO dispute settlement procedure mostly covers disputes regarding trade. Many FTAs state dispute settlement procedures are not as frequent as investor-state disputes. ${ }^{120}$

The FTA Joint Committee cannot force the offending country to remove the measure or pass an order to stop the measure from running. If a panel finds that the U.S. is in violation of its obligations under the US-JO FTA and the U.S. does not comply, Jordan at least on paper - may be to retaliate by imposing trade sanctions against the U.S. However, imposing higher tariffs on intermediate manufactured imports from the U.S.

\footnotetext{
${ }^{118}$ The use of dispute settlement mechanism in FTAs depends on many factors. The absence of secretariat support in the FTA affects the operation of the dispute settlement mechanism while the WTO system enjoys reliable logistical support from well-organized staff members. See Overview of the WTO Secretariat, available at $<$ https://www.wto.org/english/thewto_e/secre_e/intro_e.htm $>$ (last visited Feb. 1, 2018) (The WTO Secretariat has 634 regular staff. The Secretariat provides legal assistance in the dispute settlement process. The Appellate Body has its own Secretariat).

${ }^{119}$ See Bashar H. Malkawi, Arab Countries' (Under) Participation in the WTO Dispute Settlement Mechanism, 14 Flinders Law Journal 1, 7-8 (2012). Jordan, Morocco, and Oman do not make the list of top trading partners with the U.S. See U.S. Census Bureaeu, Top Trading Partners 2017, available at $<$ https://www.census.gov/foreign-trade/statistics/highlights/top/index.html >.

${ }^{120}$ In NAFTA as an example, of the total 119 cases which have been referred for dispute settlement procedures, 3 have been cases of state-to-state dispute settlement under chapter 20. See NAFTA Secretariat, Decisions and Reports, available at $<$ https://www.nafta-sec-alena.org/Home/DisputeSettlement/Decisions-and-Reports $>$ (last visited Dec. 11, 2017).
} 
could be detrimental to Jordan's economy welfare in general. ${ }^{121}$ To reduce the problem of enforcement, the US-JO FTA should be revised by introducing alternatives to retaliation such as financial damages. Until a more plausible solution is invented, Jordan will find it sensible not to spend time and cost on a complaint in anticipation of its inability to enforce even a positive panel ruling.

\section{Conclusions}

A strong dispute resolution mechanism is a core component of FTAs which must provide a reliable and stable venue to address meritorious claims and deliver enforceable results and demonstrates the commitments of each government to comply with the contractual obligations. Without this commitment, businesses will be reluctant to risk capital.

The U.S. concluded an FTA with Jordan for diverse reasons within the economic and geopolitical contexts. The current dispute settlement mechanism in the US-JO FTA has rarely if ever been invoked and should be modified to reflect legal developments as well as the possible use as a template for a comprehensive US-Middle East FTA. In making these suggested improvements, we take into account the marked disparity in both hard and soft power as well as economic resources between the parties to encourage FTA utilization and participation and promote the gains to a developing country such as Jordan. Since 2000s, the U.S. concluded other FTAs with Bahrain, Oman, and Morocco. These FTAs were negotiated and concluded around the same time approximately; therefore key characters of the dispute resolution provisions are similarly formulated.

\footnotetext{
${ }^{121}$ Developing country retaliatory measure(s) against a developed country, such as the US or EU, is highly likely to have a relatively small impact on the economies of these developed countries. See Bashar H. Malkawi, supra note 111 , at 18.
} 
The U.S. FTAs with Arab countries share some commonalities. For example, The U.S FTAs with Arab countries address disputes between the parties arising from the application or interpretation of the agreements or compliance with treaty obligations. In addition, these FTAs establish Joint Committees and sub-committees of various types to discuss issues of reciprocal interests, one of which is to resolve disagreements between the parties. Nevertheless, the specific terms and conditions of the dispute resolution provisions vary especially in the US-JO FTA.

The US-JO FTA clearly differs from other U.S. FTAs with Arab countries. The U.S. free trade agreements with Oman, Bahrain, and Morocco in some parts improve upon the dispute resolution mechanism in the US-JO FTA. These differences reflect political and economic factors underlying every agreement and the relationships between the parties. In addition, it seems that the U.S. opted for new experiments in recent FTAs with Arab countries to address some of the problems existing in the WTO in an innovative mode such as requiring financial compensation for non-compliance.

The US-JO FTA does not provide accelerated consultation period for cases involving perishable goods. The US-JO FTA is silent regarding bilateral consultation or action on proposed legislations. Also, The FTA does not prescribe a time limit within which the panel should be called or what happens in the case whereby the parties do not agree on the panel's membership. Under the US-JO FTA, there is only one final report. The US-JO FTA does not require that the panel issues an initial report on which both parties can comment. The panel report is not binding. The US-JO FTA did not provide a process for appeal or review along the lines of the WTO's standing Appellate Body. 
The US-JO FTA was affected by U.S. policy regarding environment and labor. These issues were included in the FTA. As a result, dispute settlement mechanisms came to be applied to labor and environmental obligations as well. However, the panel's jurisdiction over labor and environmental issues is narrower than other actions inconsistent with the US-JO FTA. Not every failure to enforce environmental or labor law constitutes grounds for initiating dispute settlement. Rather, the FTA parties should not fail to effectively enforce their environmental and labor laws through a sustained or recurring course of action or inaction in a manner affecting trade.

The dispute settlement mechanism in the US-JO FTA can be improved in several concrete ways. These improvements will address potential concerns and should contribute to a higher utilization of the FTA as well as serve as a template for a more expansive US-led regional FTA. While trade between the U.S. and Jordan remains modest, economies develop and disputes under the US-JO may become more likely in the future. 